\title{
KOSMAS-GYTHIO UNIT: A METAMORPHIC CARBONATE SEQUENCE OVERLYING THE PHYLLITES-QUARTZITES UNIT IN SOUTHERN PELOPONNESUS, GREECE.
}

Skourtsos E. and Lekkas S.

Sector of Dynamic, Tectonic and Applied Geology, Department Geology, National \& Kapodistrian

University of Athens,, 157 84, Athens, eskourt@geol.uoa.gr

\begin{abstract}
New data from southern Peloponnesus show the presence of a metamorphic carbonate sequence sandwiched between the Phyllites-Quartzites and the Tyros beds, the permotriassic base of the Tripolitza unit. The lithostratigraphic members of this sequence, named Kosmas-Gythio unit, are comparable to that of the Plattenkalk unit in Taygetos and Parnon mountains. It is suggested that palaeogeographically the unit belongs to the Ionian basin and its position was between the Plattenkalk unit and the Tripolitza carbonate platform. As for the Phyllites-Quartzites unit it is suggested that this unit is not a metamorphic equivalent to the Tyros Beds or the basement of the Tripolitza platform, but the base or the basement of the Kosmas-Gythio unit, and therefore of the Ionian ba$\sin$.
\end{abstract}

\section{INTRODUCTION}

The generally accepted suggestion is that the structure of the External Metamorphic Zone of the Hellenides consists of two great nappes or units: the lower one is the Plattenkalk unit (Crete-Mani), aged Upper Palaeozoic - Lower Oligocene (Psonis 1980, Thiebault 1982, Manutsoglu 1990, Aleweld 2002), while the upper one is the Phyllites-Quartzites unit, aged Upper Palaeozoic - Upper Triassic (Krahl et al. 1983). Another unit also mentioned in western Crete is that of the Tripali unit, a monotonous series of dolomitic Upper Triassic marbles sandwiched between the two previously mentioned units (Krahl et al. 1983). The Plattenkalk unit is considered to be the metamorphic equivalent of the Ionian unit, while the palaeogeographic position of the Phyllites-Quartzites is still under discussion, as it has been considered to be: a) the metamorphic basement of the Tripolitza unit (Paraskevopoulos 1964, Karakitsios 1979), b) a separate palaeogeographic domain of the External Hellenides between the Ionian zone in the west and the Tripolitza carbonate platform in the east (Jacobshagen et al. 1978), c) the permotriassic base of the dolomites of Tripali unit (Krahl et al. 1983), d) a unit deriving from the Cyclades domain (Papanikolaou \& Skarpelis 1986) and e) the metaflysch of the Plattenkalk unit (Lekkas, 1980).

New data from southern and central Peloponnesus show the existence of a metamorphic carbonate sequence tectonically sandwiched between the Phyllites-Quartzites and the low-grade metamorphism Tyros Beds that constitute the permotriassic base of the Tripolitza unit. The fact that this sequence a) tectonically overlies the Phyllites-Quartzites and underlies the Tyros beds, b) consists of dolomites and marbles that are different in facies from those found in the Tyros beds, as well as from the limestones and the dolomites of the Tripolitza carbonate platform and c) differ from the marbles intercalations that are found in the Phyllites-Quartzites, led the authors think of this as an individual geotectonic unit and name it "Kosma-Gythio unit". 


\section{DESCRIPTION OF THE KOSMAS - GYTHIO UNIT}

\subsection{The Kosmas-Gythio Unit north of the town of Gythio}

In the town of Gythio as well as north of this, there is a big outcrop of marbles, which was initially mapped by Thiebault (1982) and later by Lallemant et al. (1984), Dimadis (1987) and Doutsos et al. (2000), who related it to the Plattenkalk unit. On the contrary, Manutsoglu (1990) placed it in the carbonate platform of Tripolitza.

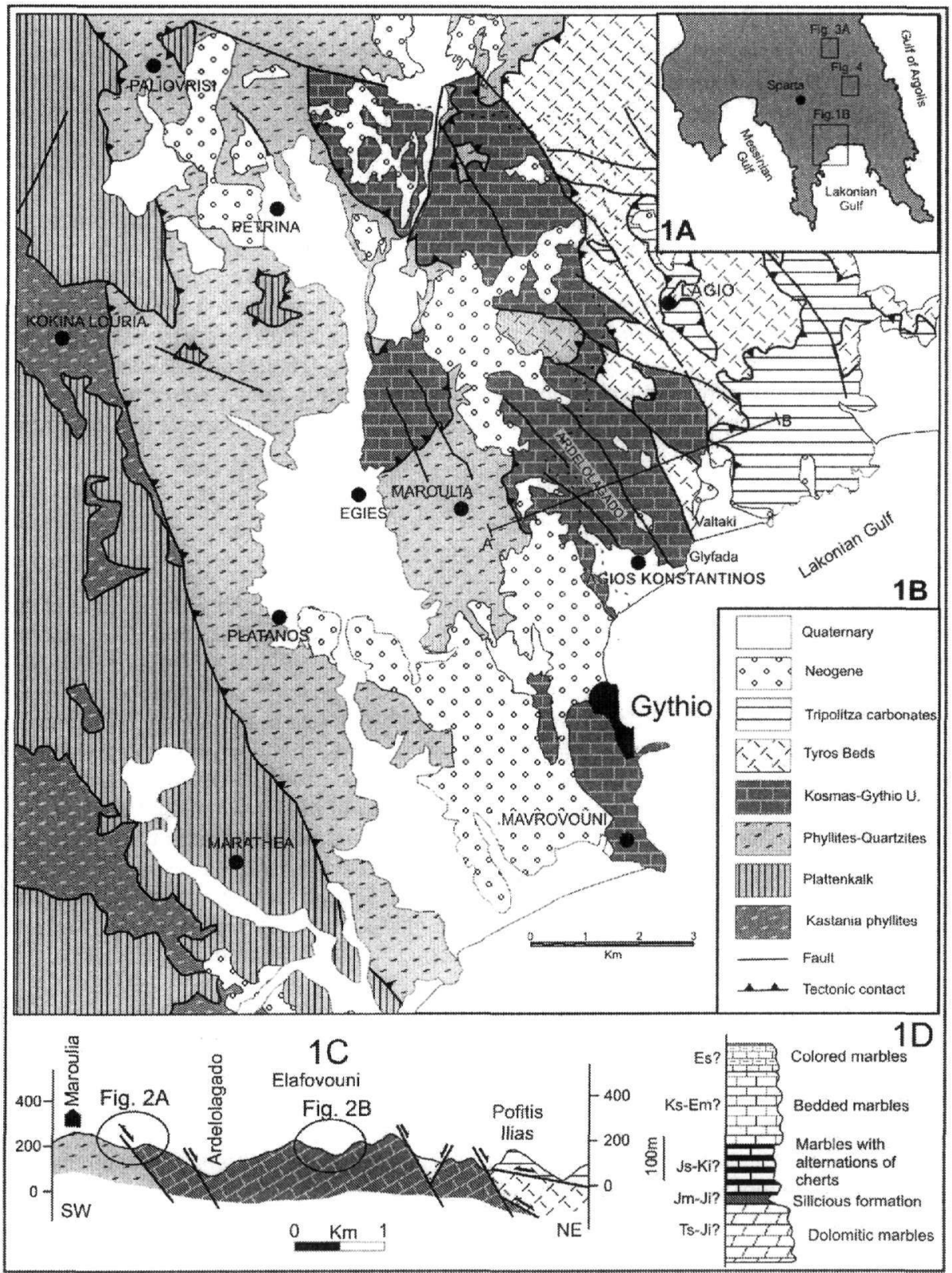

Fig. 1: Geological map of the broad area of Gythio (modified from Dimadis, 1987) (1B). The Kosmas-Gythio unit overlie the Phyllites-Quartzites unti and underlie the Tyros Beds (1C). Lithostratigraphic column of the KosmasGythio unit from the region og Gythio (1D). The position of the study area is shown in figure $1 \mathrm{~A}$. 
In the region of Gythio the outcrops of the Phyllites-Quartzites unit cover an area of tens of $\mathrm{km}^{2}$. It consists of mica schists, quartzites, metaconglomerates and metamorphic ultrabasic rocks (Papanikolaou \& Skarpelis, 1988). The main mineral assemblage is glaucophane, chloritoid, albite and chlorite. In the west, the Phyllites-Quartzites overlie the Plattenkalk unit along the villages of Arna, Agia Marina, Kokina Louria as far as the beach of Platana. These outcrops were placed by Thiebault (1982) in the lower phyllitic nappe of the "Main Crystallic System" or in the Arna unit by Papanikolaou \& Skarpelis (1988).

On the contrary, towards the east the Phyllites-Quartzites underlie the marbles found in the north of Gythio (Fig. 1B, 1C). The most characteristic position where the fault contact of the marbles and the mica schists can be seen is in the east of Maroulia village, where the fault contact dips 35$45^{\circ}$ to the $E$ (Fig. $2 \mathrm{~A}$ ). It is characterized by the presence of fault rocks (fig. $2 \mathrm{~A}$ ), such as cataclasites and gouges. The thickness of this intensely brecciated zone is more than $30-40 \mathrm{~m}$.

A lithostratigraphic section was made in these marbles along the road connecting Agios Konstantinos with Laggio. There, it was noted that the lower formation consists of dolomites and dolomitic marbles (Fig. 1D). In their lower part these are massif, but soon they become thick-bedded grey-whitish dolomites and marbles. Upwards the marbles become bluish with intercalations of grey cherts. Then follows a siliceous formation having porous, whitish-yellowish quartzites about $20 \mathrm{~m}$ thick (Fig. 1D, 2B). This formation passes to alternations of bedded, bluish marbles and whitish cherts (Fig. 1D, 2B). In Glyfada, the previous formation underlies marbles that are thick-bedded, whitish to yellowish and lacking cherts, passing upwards to alternations of whitish and reddish marbles with rare beds or nodules of silex. Intercalations of thin-bedded to bedded bluish marbles with white and black colored silex nodules were also observed in the valley of Ardelolagado. The thickness of this formation is more than $200 \mathrm{~m}$. Towards the southwest this formation passes gradually to bedded, whitish marbles. The thickness of this succession is considered to be $\sim 700-800 \mathrm{~m}$.

The usual mineral paragenesis of the marbles of this series is calcite + quartz + plagioclast while in the thin schist intercalations is calcite + albite \pm white mica \pm chlorite + quartz.

This outcrop is intersected by high-angle normal faults striking NW-SE to ESE-WNW. In some places, mainly along the valley of Ardelolagado the sub-horizontal tectonic contact between the overlying Tyros beds and the underlying marbles of Kosmas-Gythio unit can be observed. The continuity of this fault to the east is cut by NW-SE normal faults.

\subsection{The Kosmas-Gythio Unit in Parnon Mt.}

The outcrops of the Kosma-Gythio unit on Mount Parnon can be seen in the geological maps in figures $3 A$ and 4 , where they have the form of big tectonic wedges, which are sandwiched between the underlying mica schists of the Phyllites-Quartzites unit and the overlying Tyros Beds. Their thickness, compared to that of the Gythio outcrops, is small and reaches only $80-100 \mathrm{~m}$.

The fault contact between this unit and the Phyllites-Quartzites is a low-angle normal fault (Fig. $2 \mathrm{D}, 2 \mathrm{E}$ ) with a sense of shear "the top to the NE" and is characterized by the presence of a cataclasite about 0.5-1.0 m thick, having ochre color and glassy matrix and mica or carbonate clasts. This state rarely stays the same as it has been destroyed by later gravity slides of the marbles on the underlying mica schists of the Phyllites-Quartzites.

The rocks of the unit are intensely brecciated by many faults, most of which stop at the basic fault contact with the Phyllites-Quartzites. Many times these faults juxtapose different facies of marbles. For that reason, it was impossible to give a representative, lithostratigraphic section for the unit, so only local lithological observations were made about the facies of the marbles found from place to place.

The marbles of the Kosmas-Gythio unit are usually whitish to bluish, massif or thick-bedded marbles (Fig. 2C) with rare intercalations of whitish or dark cherts. Near their contact with the Tyros Beds, in the northwest of Kosma, there are alternations of bedded, whitish and reddish marbles with rare chert nodules. In the north of Profitis Ilias summit, there are whitish, saccharoid dolomites, which upwards pass to whitish, coarse grained marbles. In the southeast of Vigla there are dark and reddish marbles in alternations, which dip to the NE. In the west of Kosma, alternations of bedded, whitish, reddish and greenish marbles are exposed, under which there is a series of brown col- 
colored marbles with intercalations of mica schists. A similar sequence was found in the east of the school in Kosmas, on the road leading to the Anemotripa stream.

In the region of Podaras a lithostratigraphical section was made along which it was noticed that the lower part of the unit consists of cellular dolomites followed by whitish thin-bedded marbles and dolomitic marbles, which dip $20^{\circ}$ to the SW (Fig. 2F). Cataclastic rocks can be seen over these carbonates, that are ochre colored and 3-4 m thick. Then, with the presence of about 5-10 $\mathrm{m}$ of brown and red pelites, intensely foliated, dark grey dolomites of the Tripolitza unit follow.

In the west of Podara there are thick outcrops of the Kosma unit (Fig. 4), which consist of whitish, bedded marbles dipping to the SW. Towards the north, the marbles become dolomitic and later white pure dolomites.
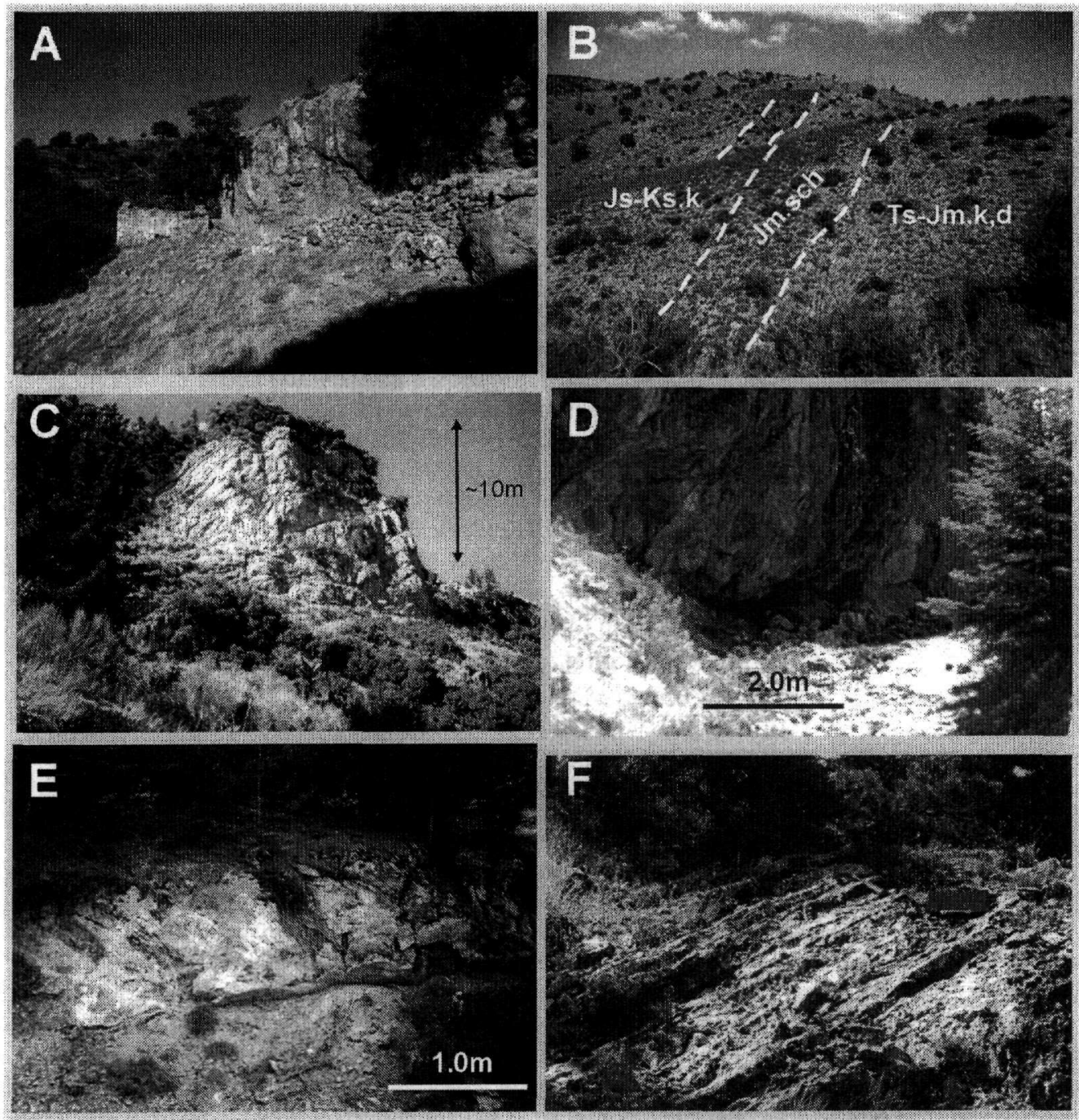

Fig. 2: The fault contact between Phyllites-Quartzites and the marbles of Kosmas-Gythio unit (A). The dolomitic marbles passes upwards to a siliceous formation and by its turn to thin bedded bluish marbles with intercalations of whitish cherts (B). Whitish, thick bedded dolomitic marbles from the region of Kosmas (C). The lowangle normal fault separating the dolomitic marbles of Kosmas-Gythio unit from the Phyllites-Quartzites west of Kosmas (D) and in Podaras (E). Thin bedded marbles in the north of Podaras (F). The locations of the photos are shown in figures $1 \mathrm{~A}, 3 \mathrm{~A}$ and 4 . 


\section{DISCUSSION}

Until now the most important reference for the presence of marbles over the Phyllites-Quartzites unit was that of Alexopoulos \& Lekkas (1999). These authors describe a sequence of multicolored marbles in the southern Mani peninsula passing to metaflysch, which overlies tectonically the Phyllites-Quartzites unit. More specifically, in the area between Vathia and Porto Kagio, the two researchers noticed that the Phyllites-Quartzites unit not only overthrust the metaflysch of the Plattenkalk unit, but it also underlies a series that looks like the upper part of the Plattenkalk, and which is overturned in some places. In order to explain this succession of nappes, which was quite unusual, Alexopoulos \& Lekkas (1999) thought that the presence of the multicolored marbles above the Phyllites-Quartzites is not due to the Upper Oligocene-Lower Miocene thrust tectonics, but that it is due to late gravity slides

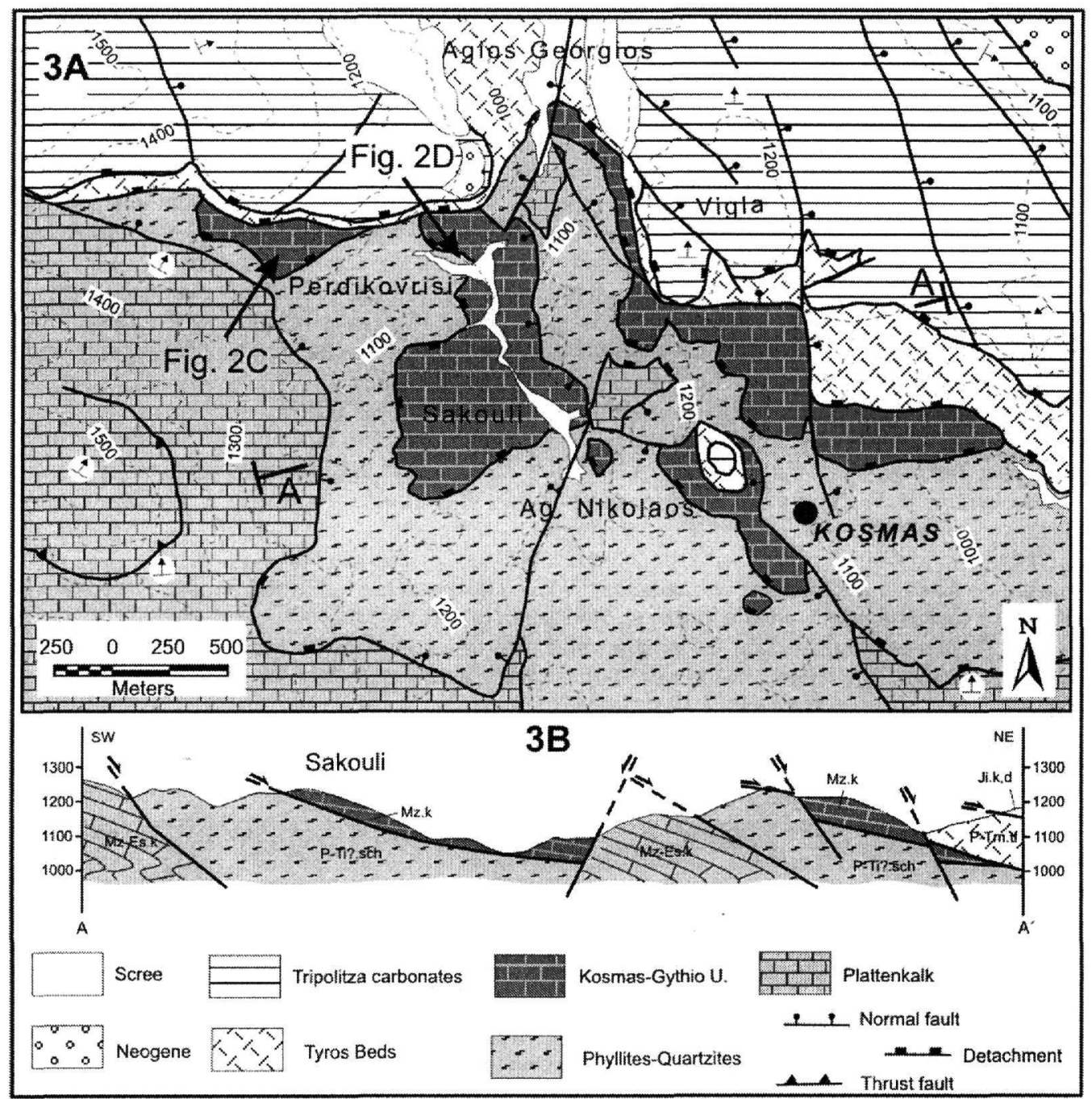

Fig. 3: Geological map (A) and section (B) from the region of Kosmas. The location of the geological map is shown in figure $1 \mathrm{~A}$ and that of the section in figure $3 \mathrm{~A}$.

Moreover Aleweld et al. (1994) described the Miaouli subunit in northwestern Taygetos which has a tectonic position similar to that of the Kosmas-Gythio unit in eastern Parnon and Gythio. This subunit underlies the Tyros Beds and is the upper subunit of the Phyllites-Quartzites (Aleweld et al. 
1994). According to those authors, as the relations between the different subunits that distinguish the Phyllites-Quartzites are of tectonic origin, the contact of the Miaouli subunit with the others is also tectonic. The Miaouli subunit is found in the villages of Karveli and Ladas and is separated in two members. The lower member consists of a series of dark quartzites and schists, with thin marbles intercalations, the main mineral assemblage of which is chlorite, epidote and Ca-clinozoisite. The upper member consists of bedded, whitish marbles which pass upwards to bedded marbles with intercalations of schists with mica, chlorite and clinozoisite. Aleweld et al. (1994) compared these carbonates with those described by Braüer et al. (1980) in eastern Lakonia and they are Anisian in age. In fact, they thought that these marbles are the initial, permotriassic, sedimentary cover of the Phyllites-Quartzites, that is, a time, but not metamorphically and lithophasically, equivalent of the Tyros Beds (Aleweld et al., 1994). Braüer et al. (1980) describe two different series in eastern Lakonia: the series of Plytra and the series of Molai. The researchers above defined Anisian age in crystal limestones, which constitute the upper subunit of the Plytra series. These limestones overlie a volcano-sedimentary sequence, and a series of phyllites and quartzites. In the first one they found fossils of Norian age. Later though, Gerolymatos et al. (1982) and Danelian et al. (2000) classified the crystal limestones in the Angelona nappe, which belongs to the Pelagonian Zone, and the volcano-sedimentary sequence in the Tyros Beds. Finally, the series with the phyllites and quartzites was compared to the Phyllites-Quartzites unit. Therefore, the comparison made by Aleweld et al. (1994) with the Anisian crystal limestones of Braüer et al. (1980) does not seem to apply.

So, regardless of what the Molai series represents, what can be concluded from the above is that in the regions of south Mani, Gythio, NW Taygetos and Parnon Mt, there is a metamorphic carbonate nappe overlying the Phyllites-Quartzites. This nappe is the Kosma-Gythio unit.

A question that must be answered is whether the Kosmas-Gythio unit is a separate tectonic nappe, meaning that it has its own palaeogeographic position, as it is with the Plattenkalk, the Tripolitza and the Pindos units, or whether it is a big thrust slice that belongs to one of the already known palaeogeographic domains of the Ionian and Tripolitza zones.

The alternation of the lithostratigraphic members of the Kosmas-Gythio unit is almost the same with that of the Plattenkalk unit and this allows their comparison. The only objection one might have is the fact that there is no palaeontological evidence confirming this. But the presence of metaflysch in the overturned nappe of southern Mani, in which fossils of the Lower Oligocene have been found (Alexopoulos \& Lekkas 1999) seems to confirm this theory.

If this nappe indeed derives from the Ionian basin, then this means that:

-the Phyllites-Quartzites unit has been sandwiched between the two metamorphic carbonate series of the lonian zone s.l. and not between the Plattenkalk and the Tripolitza units and

-the Phyllites-Quartzites unit, at least for southern Peloponnesus, is not a more metamorphic equivalent of the Tyros Beds or the basement of the Gavrovo-Tripolitza unit, but the base or the basement of the lonian Zone s.l.

A quite similar view had been given just a few years ago by Blümor (1998) for the PhyllitesQuartzites of eastern Lakonia and Kythira. Based on metamorphic data he had proposed that the Phyllites-Quartzites unit is the basement of the Plattenkalk unit and that today's tectonic position of the nappe is due to geodynamic processes in the accretionary wedge in the Hellenic subduction zone.

It is reminded that the first who expressed such a theory were Krahl et al. (1983). These authors presenting the stratigraphic succession of the Phyllites-Quartzites Series in western Crete, mention that in the locations Mana Akonistra and Keramoti there are whitish, bedded dolomites, aged Upper Triassic, which, while lying tectonically on the base of the Phyllites-Quartzites Series, are stratigraphically placed on the top of it. These dolomites can be compared with the base of the Tripali group, as they are equivalent as far as facies and age are concerned (Krahl et al., 1982, 1983). Consequently, the Phyllites-Quartzites series is considered by these researchers to be the basement of the Tripali group, a group which is also related to the low, Jurassic in age, parts of the Plattenkalk unit.

Two are the most important differences between the dolomites in Akonistra and those of the Kosmas-Gythio unit: a) in western Crete the dolomites are underlying the permotriassic series of the Phyllites-Quartzites, while in southern Peloponnesus they are overlying it and b) the contact of the dolomites with the Phyllites is stratigraphic, while in Parnon Mt and Gythio the observed contact 
is tectonic in origin. So, in order to connect these two, the contact of the dolomites of the KosmasGythio unit with the underlying schists of the Phyllites-Quartzites should at some time have been stratigraphic. Such evidence has not yet been found.

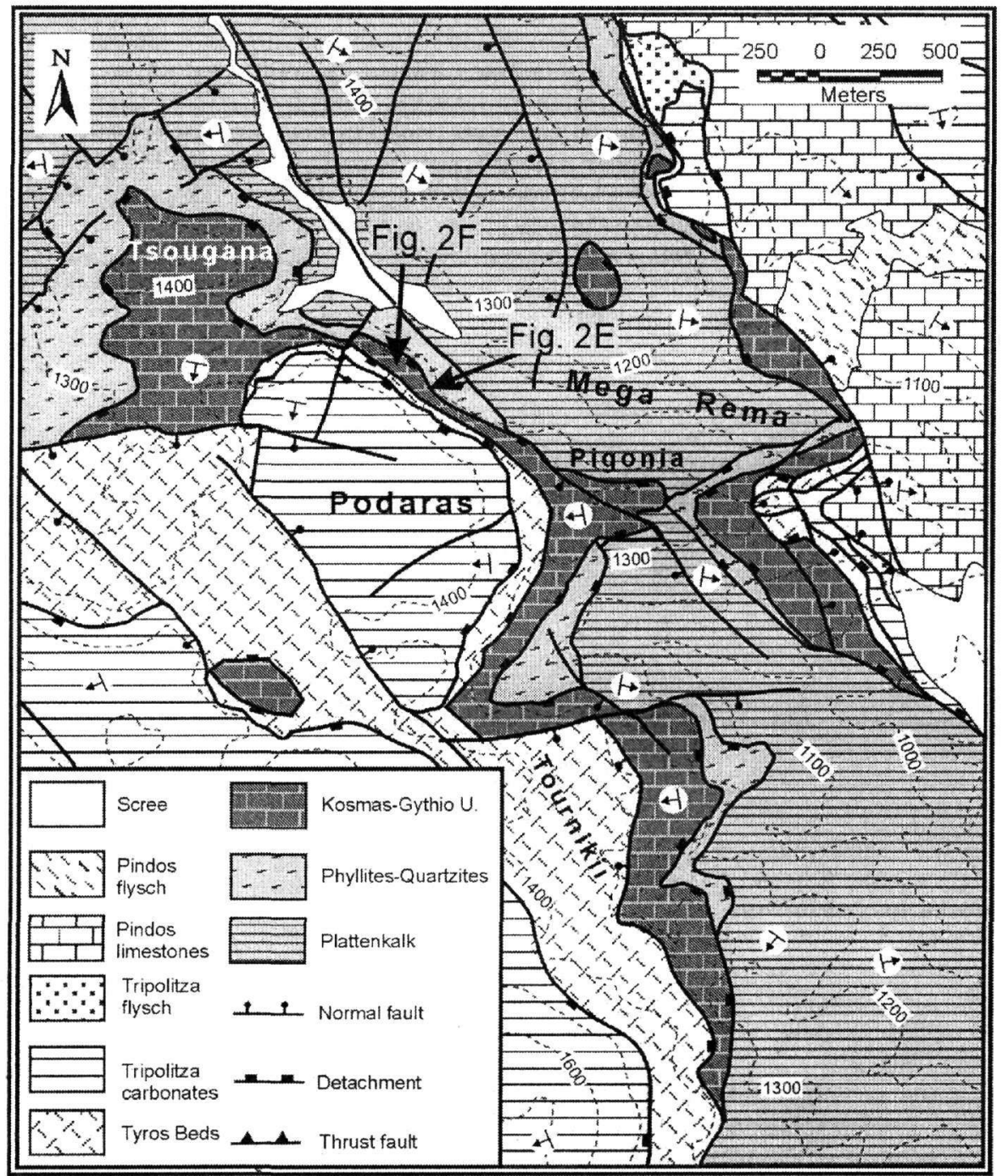

Fig. 4: Geological map of the region of Podaras. The Kosmas-Gythio unit is sandwiched between the PhyllitesQuartzites and the Tyros Beds. The thickness of the unit is limited. The location of the geological map is shown in figure $1 \mathrm{~A}$.

Moreover, in central-northern Crete, in the west of the city of Iraklio, there is a carbonate series named "Vasilikos marbles", the tectonic position of which has been an open question for various researchers [see bibliographic review by Alexopoulos (1995)]. The most prevailing theories are two: The first one supports that the carbonate matrix of Vasilikos belongs to the Tripolitza nappe (Aubouin \& Dercourt 1965, Epting et al. 1972) and the second that it is part of the PhyllitesQuartzites unit (Creutzburg \& Papastamatiou 1966, Hall \& Audley-Charles 1983, Richter \& Kopp 1983 , Krahl et al. 1988). Detailed geological mapping of the area showed that the marbles in Vasilikos overlie tectonically the "Rogdias-Fodele phyllites" and underlie the "phyllitic unit of Achlada" (Alexopoulos, 1995). The fact that they overlie the Phyllites-Quartzites ("Rogdias-Fodele phyllites") (Alexopoulos, 1995) shows, first of all, that they are comparable to those of the Kosmas-Gythio 
nappe. In this comparison though, there is a contrast caused by their overlying on the "Phyllites of Achlada" (Alexopoulos, 1995). If the latter can be compared to the Tyros Beds, as they also contain meta-andesites, then the comparison above may apply.

So, it can be said that the nappe of Gythio and therefore the rest of the outcrops of marbles with similar tectonic position, belong palaeogeographically to the lonian basin, just as it happens with the Plattenkalk unit. Moreover the Kosmas-Gythio unit was flanked by the Plattenkalk unit to the west and the Tripolitza unit to the east (figure 5), accepting that the nappe motion was from the east to the west (Jacobshagen et al 1978). During the Lower Miocene Plattenkalk and Kosmas-Gythio units were subducted under the composite thrust pile consisting by the Tripolitza and Pindos units, where they were metamorphosed under HP/LT conditions (Thiebault 1982, Doutsos et al 2000). Continuous underplating process brought Phyllites-Quartzites unit with its sedimentary cover, the Kosmas-Gythio unit, on top of more external parts of the Ionian Basin. Gradually that process uplifted these units towards the earth surface where they are seen today in the tectonic windows of Taygetos and Parnon Mounts (Doutsos et al 2000).

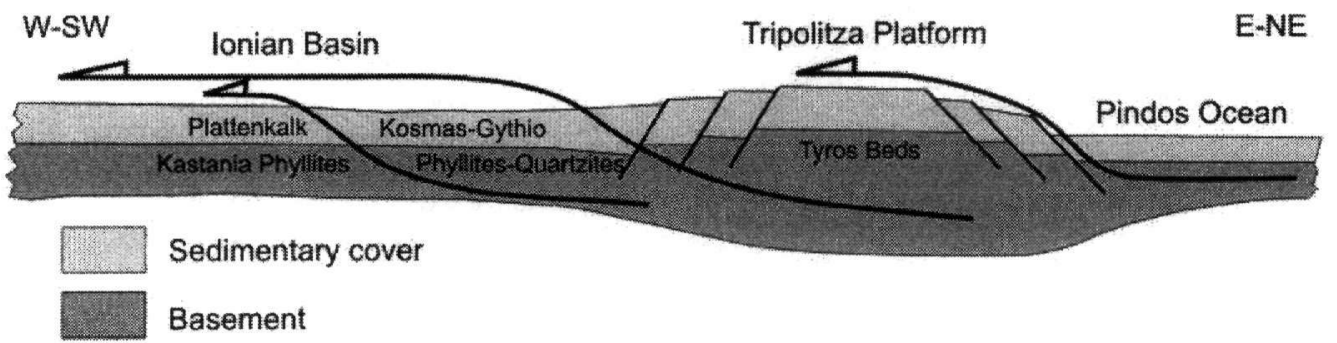

Fig. 5: Mesozoic palinspastic cross section through the External Hellenides with the main future thrust fault. The position of the Kosmas-Gythio unit was in the internal part of the Ionian Basin and closer to the Tripolitza platform.

\section{CONCLUSIONS}

From the above presented data, the following conclusions can be made:

1. In southern Peloponnesus it is observed that a metamorphic carbonate sequence overlies the Phyllites-Quartzites and underlies the Tyros Beds. This sequence is called Kosmas-Gythio unit.

2. The main outcrops of this unit are observed in a large area north of Gythio town and in the eastern slopes of Parnon Mt. It is possible that the Miaouli subunit and the gravity nappe in southern Mani described by Aleweld et al. (1994) and by Alexopoulos \& Lekkas (1999), respectively belong to this unit.

3. The Kosmas-Gythio unit consists of carbonate rocks with some intercalations of cherts. In southern Mani a flysch sequence can be observed on its top. The total thickness of the unit in the region of Gythio is $\sim 700-800 \mathrm{~m}$. while it is limited in the rest of the outcrops.

4. It is suggested that the palaeogeographic position of the unit was in the internal lonian basin, between the Plattenkalk unit in the west and the Tripolitza platform in the east. This suggestion is based on the similarity of the lithostratigraphy that the Kosmas-Gythio and Plattenkalk units show.

5. The Phyllites-Quartzites unit is not the basement or the base of the Tripoltza unit, but the basement or the base of the Kosmas-Gythio unit and therefore of the Ionian basin.

6. The External Metamorphic Zone of the Hellenides consists of a nappe-pile deriving from the Ionian basin that piled up during the subduction of this basin under the Tripolitza platform. This suggestion reinstates the one proposed by Blumör (1998) and Aleweld (2002) for the PhyllitesQuartzites of Lakonia and Kythira, as well as confirming that supported by Krahl et al. (1983) for the Phyllites-Quartzites and the Tripali unit in western Crete. 


\section{REFERENCES}

Aleweld E., Groebke P. and Zacher W., 1994. The contact zone between Phyllite-Quartzite and GavrovoTripolis unit in the Taygetos mountains, Messenia.: Bull. Soc. Geol. Greece, v. 30, p. 147-152.

Alexopoulos A., 1995. The hydrogeological conditions of the Vasiliko Marbles (north-central Crete. 30 Hydrogeological Conference, p. 76-91.

Alexopoulos A. and Lekkas S., 1999. The tectonic structure of Tainaro (Mani) Peninsula (Southern Peloponnese, Greece): N. Jb. Geol. Palaont. Mh., v. 1999, p. 698-704.

Aleweld E., 2002. Seriengliederung und Deckenbau im nördlichen Taygetos-Gebirge (Südpeloponnes, Griechenland): pHD thesis, Universität Müchen, Müchen, 150 p.

Aubouin J. and Dercourt J., 1965. Sur la geologie de l'Egee: Regard sur la Crete (Grece): Bull. Soc. Geol France., v. VII, p. 787-821.

Blümor, T., 1998, Die Phyllit-Quarzit-Serie SE-Lakoniens (Peloponess, Griechenland): Hochdruckmetamorphite in einem orogenen Keil: Frankfurter geowiss. Arb. Serie A, v. Bd. 17: Frankfurter, 187 p.

Braüer R., Ittner R. and Kowalczyk G., 1980. Ergebnisse aus der "Phyllite-Serie" SE-Lakoniens: N. Jb. Geol Palaont. Mh., v. 3, p. 129-144.

Creutzburg N. and Papastamatiou J., 1966. Neue beitrage zur geologi der insel Kreta: Geol. Geophys. Res., v. 9 , p. 173-185.

Danelian T., Lekkas S. and Alexopoulos A., 2000. Découverte de radiolarites triasiques dans un complexe ophiolitique à l'Extrême-Sud du Péloponnèse (Agelona, Lakonie, Gréce): C. R. Acad. Sci. Paris, v. 330, p 639-644.

Dimadis G., 1987. Geological map "Gythio sheet". I.G.M.E.

Doutsos T., Koukouvelas I., Poulimenos G., Kokkalas S., Xypolias P. \& Skourlis K. 2000. An exhumation model of the south Peloponnesus, Greece. International Journal of Earth Science 89, 350-365.

Epting M., Kudrass H. R., Leppig U. and Schafer A., 1972. Geologie der Talea Ori/Kreta: N. Jb. Geol. Palaont. Abh., v. 141, p. 259-285.

Gerolymatos I., Dornsiepen U. and Trifonova E., 1982. Vorkommen von hoheren zentralhellenischen Deckeneinheiten in Lakonien (Peloponnes, Griechenland): Prakt. Akad. Athinon, 57, p. 247-261.

Hall R. and Audley-Charles M. G., 1983. The structure and regional significance of Talea Ori, Crete: Journal of Structural Geology, v. 5, p. 167-179.

Jacobshagen V., Richter D. and Makris J., 1978. Alpidic development of the Peloponnesus, in Closs, H., Roeder, D. and Schmidt, H., eds., Alps, Appennines, Hellenides: Stuttgart, E. Schweizerbart'sche Verlagsbuchhandlung,, p. 415-423.

Karakitsios V., 1979. Contribution a l'étude géologique des Hellenides: Étude de la region de Sellia (Crète moyenne-occidentale, Grèce). Les relations lithostratigraphiqueset structurales entre la série des Phyllades et la série de Tripolitza: These, 3eme cycle thesis, University Pierre et Marie Curie, Paris.

Krahl J., Eberle P., Eickhoff J., Forster O. and Kozur H., 1982. Biostratigraphical investigations in the PhylliteQuartzite Group on Crete island, Greece: International Symposium on the HellenicArc and Trench (H.E.A.T.), p. 306-323.

Krahl J., Kauffmann G., Kozur H., Richter D., Forster O. and Heinritzi F., 1983. Neue Daten zur Biostratigraphie und zur tektonischen Lagerung der Phyllit-Gruppe und der Trypali-Gruppe aufder Insel Kreta (Griechenland): Geol. Rundsch., v. 72, p. 1147-1166.

Lallemant S. 1984. La tranversale Nord-Maniote. Etude geologique et aeromagnetique d'une structure tranverse a l'arc Egeen externe. Unpublished These, 3eme cycle thesis, Universite Pierre et Marie Curie.

Lekkas S., 1980. Les phyllades du Peloponnese: un metaflysch ionien chevauche par la serie de GavrovoTripolitza (Grece): C. R. Acad. Sci. Paris, v. 291, p. 21-24.

Manutsoglu E., 1990. Tektonik und metamorphose der Plattenkalk-Serie im Taygetos (Peloponnes, Griechenland): Berliner geowiss. Abh. (A), v. 129: Berlin, $82 \mathrm{p}$.

Papanikolaou D. and Skarpelis N., 1988. The blueschists in the external metamorphic belt of the Hellenides: Composition, structure and geotectonic significance of the Arna Unit: Ann. Geol. Pays Hell., v. 33, p. 47-68.

Paraskevopoulos G., 1964. Die alpine Dislokotionsmetamorphose im zentral Peloponnesisch-Kretschen metamorphen System: N. Jb. Mineral. Abh., v. 101, p. 195-209.

Psonis K.Th., 1981. About the presence of Permian (?) - Lower Triassic beds as a basement of the Plattenkalk series in the Taygetos Mt. Description of a continuous section. Ann. Geol. Pays. Hell., 30, 578-587.

Skourtsos E. 2002. The geological structure of the eastern boundaries of the tectonic window of Parnon Mt. Unpublished Phd Thesis, National and Kapodistrian University of Athens, 396p (in Greek with extended English abstract).

Thiebault F., ed., 1982. Evolution geodynamique des Hellenides externes en Peloponnese meridional (Grece), v. 6, Societe Geologique du Nord, 393 p. 